had imagination, a real love of science, and far more of real science in him than most medical men. If he is not strictly to be regarded a man of science, at least he believed in science wholeheartedly, and knew its ways. This gave him one great qualification for an administrative scientific post, and when we add to this his administrative achievements, as D.G.A.M.S. before the War, we cannot wonder that Lord Haldane, best aware of them, urged in 1910 the appointment of Keogh to the rectorship of the Imperial College of Science, which at that time, above all things, needed a talented administrator at its head. This post Keogh held actively from 1910 until 1914, when he was recalled to his old position at the War Office.

After the War, Keogh returned to it eagerly, and retired reluctantly from it only when he reached the age of sixty-five years in 1922. How much he loved the work can be gauged from the fact that at the most critical period of the War he said, with a rueful smile to the writer, that he was longing "to get back to South Kensington". Many readers of NATURE will have personal recollections of Keogh at the Imperial College. They may, perhaps, be puzzled to pick out any conspicuous act of reorganization likely, outside the College, to be associated with his name. If those who had the happiness of holding teaching or other office at the College during his rectorship are asked what he did, they too cannot, or will scarcely stop to tell you. For all thoughts of what he did are overwhelmed by the thought of what he was.

Keogh was above all else a veritable knight, a Christian Irish Catholic gentleman, endowed with all the graces that these words imply, not forgetting the savouring salt of humour. No wonder he was so much beloved by those who were nearest to him, and honoured and respected by those further removed who came into contact with him. By his War work he earned his place among the greatest who have served mankind, and incidentally to the work, he stood a noble figure bent on the advancement and right use of natural science.

A. S.

\section{Mr. R. R. Webb}

Robert Rumsey WeBB, the last of the famous coaches for the old Mathematical Tripos, died in Cambridge on July 29, at the age of eighty-six years. He was born at Monmouth on July 9, 1850 and went up to St. John's College, Cambridge, in 1868 as a sizar. In 1870 he was admitted a scholar of the College; in 1872 he was Senior Wrangler and first Smith's Prizeman. His election to a fellowship followed immediately; in 1878 he was appointed College lecturer in mathematics, holding this post until 1911 ; from 1878 until 1893 he was also lecturer at Emmanuel College. He retained his fellowship until his death, and he lived in rooms in College until a few years ago, when he moved to the house of his former 'gyp'.

From the date of his degree, Webb devoted his energies to training pupils for the competitive struggle of the Tripos. He was one of the famous line of coaches which included Hopkins, Routh and Besant ; he worked his men hard, but, as the letters which appeared in The Times after his death testify, he inspired and retained their affection, as well as their admiration for the masterly way in which he could manipulate such things as 'moving axes' in rigid dynamics and differential geometry. Naturally, in later days, after he had given up dining in Hall, for reasons variously reported, he became somewhat of a legendary figure. For example, the story was told that, in term time, after a strenuous morning's teaching, it was his invariable practice to go by train to Royston and walk the thirteen miles back to Cambridge, arriving so precisely at the same time each day that the College porters set their clock by him.

Webb did not take a great share in University business, though to the end of his life he was keenly interested in what was going on and, even in his seclusion, he always seemed to know the latest gossip. He examined four times for the Mathematical Tripos; the present Vice-Chancellor of the University recalls how hard he was made to work solving Webb's problems, and how much mathematics he learnt, when he was a co-examiner in 1905 and 1906.

Webb's published work is small in volume, but he was always interested in the progress of mathematics, and kept in touch with many of its developments, even after his retirement; his rooms were crowded with mathematical periodicals and treatises, as well as with paper-backed novels, in French and other languages. He had been a member of the London Mathematical Society since 1873 and he certainly attended one meeting, in January 1878, when the minutes record that "Prof. Cayley gave an expression for the surface of an ellipsoid which had been communicated to him by Prof. Tait", and "Mr. Webb made a few remarks upon the subject". On this occasion, Webb was persuaded to print his own version, and the result is "Some Applications of a Theorem in Solid Geometry" (Messenger of Math., 9,$170 ; 1880$ ), one of eight papers appearing under his name in the Messenger, vols. 9-11, the most considerable of which deal with dynamics and elasticity. $\mathrm{He}$ also published a paper on attractions in the Quarterly Journal $(14,98 ; 1877)$, and communicated in 1886 a short note "On the Problem of Three Moments" to the Cambridge Philosophical Society (Proc., 6, 42 ; 1889). But he never could be persuaded to work up into a book any of his numerous manuscripts, which he was so generous in lending.

\section{WE regret to announce the following deaths :}

Prof. Henry Sewall, emeritus professor of medicine in the University of Colorado, an authority on human physiology and tuberculosis, on July 8, aged eightyone years.

Mr. C. F. Talman, meteorologist in the U.S. Weather Bureau since 1922, on July 24, aged sixty-one years.

Prof. Frédéric Wallerant, formerly professor of mineralogy in the University of Paris, aged seventy. eight years. 